\title{
Management organization accounting for the responsibility centers
}

\author{
I $G$ Akhmetova* ${ }^{*} A$ A Derbenyova, $R R$ Dyganova and $E A$ Husainova \\ Kazan State Power Engineering University ", 420066, Kazan, Krasnoselskaya St., 51
}

\begin{abstract}
The paper is devoted to the problem of applying management accounting for responsibility centers in practice, also revealed technology for practical implementation in production. In order to obtain reliable data on the effectiveness of this separation technique, a deep research is needed, taking into account the industries characteristics in which it can be used.
\end{abstract}

\section{Introduction}

In modern conditions, one of the management accounting features is the obligation to determine costs, not only for the enterprise as a whole, but also for responsibility centers and places of formation within the organization. The responsibility center refers to activities led by a responsible person who has the right and the ability to make decisions. Cost Location is a geographically separate organization division where costs are incurred. It is not always associated with a personal obligation for the amount, appropriateness and economic costs feasibility.

The accounting by cost centers and responsibility centers organization allows you to decentralize cost management, look after the fixation at all management levels, use non-ordinary methods of cost control taking into account each unit particularities, identify overhead costs and, ultimately, greatly increase economic efficiency.

\section{Management accounting for the responsibility centers}

Management accounting is a mandatory subsystem management organization. Certain specifics of the management apparatus requirements for the provided accounting information are contained in the fact that there must be an inverse relationship between the enterprise management mechanism characteristics. With the development competitiveness in a market environment there is a rapid increase in the number of all types administrative decisions.

As a result, the operational information flow grows at high speed, the central office is overloaded with it, and the central administrative apparatus activity becomes ineffective by such actions.

Thus, the quality management system development is currently relevant for many enterprises. The starting point for creating a system is an allegory of responsibility for making decisions and defining the responsibility structure centers in an enterprise. In the future, for each of the latter, goals are determined, plans are drawn up, results are recorded, and the managers and employees activities are evaluated. The cost accounting organization in the context of responsibility centers is an important moment in the cost accounting development.

It seems reasonable to show the management accounting division materiality by responsibility centers for more efficient and timely control and economic entity's activities management, increasing responsibility for the production results and business activities at all management levels.

Tasks:

-analyze the mechanism of accounting formation and analytical support for internal divisions, using management accounting tools for responsibility centers;

- consider the accounting management classification by responsibility centers;

- to reveal the economic accounting essence for responsibility centers in enterprises;

- to argue the rational using in management accounting enterprises at responsibility centers for more effective control and management;

- to work out guidelines for internal audit, analyzing the performance and effectiveness of individual enterprises departments.

To conduct a cost accounting study by responsibility centers, observation methods, data analysis from various theoretical and practical sources, a results processing method, findings identification and practical implementation are traditionally used.

Researches devoted to cost accounting for responsibility centers have occurred in various scientific publications, as well as in several reports and scientific and practical nature conferences, and have been published as articles. This indicates the research applicability in the scientific and academic field.

Based on domestic and foreign authors scientific works analysis (Nikolaevskaya O.E., Mishina Yu.A.,

* Corresponding author: irina akhmetova@mail.ru 
Drury K. and others), we can conclude that the management accounting subject is organization segments production activity, therefore, sometimes management accounting is called center accounting responsibility.

In our opinion, the concept of management accounting is much broader, since it covers a wide production range, financial, and investment activities of an organization based on individual structural divisions planning, monitoring and evaluating the cumulative activities.

A lot of work of foreign and domestic authors are interested in management organization accounting for responsibility centers (Ivashkevich VB, Vakhrushina MA, Foster J., Sheremet A. D, Horingen H. T.). Each author gives his own definition of the responsibility center.

Vakhrushina M.A. understands the responsibility center as "the structural unit of the organization, headed by the head, who controls in a certain extent the costs, revenues and funds invested in this business segment".

Foster, J, and Horigren, C.T. define the responsibility center as "the organization segment whose managers are accountable for a specific area of the work".

Ivashkevich V.B. believes that "the responsibility center is an activity area endowed with the rights and manager duties of a certain management level, this division can take into account the fulfillment by their managers of the responsibilities assigned by the administration. The centers are created on the basis of the existing linear-functional management structure on the basis of functional departments and enterprise services.

Analyzing these definitions, it is possible to make a general conclusion that the responsibility center should be understood as the structural units created on the management apparatus departments basis that control and regulate financial flows, as well as determine the directions of spending cash flows.

There are four types of responsibility centers in management accounting:

- cost centers;

- revenue centers;

- profit centers;

- investment centers.

This responsibility centers classification is based on the criterion of the financial statements of their managers, determined by the powers breadth granted to them and the responsibility completeness.

Cost centers formation should be based on the study and analysis of organizational and technological features.

Also, taking into account the studied experience of Russian industrial enterprises, it can be concluded that this responsibility centers type is Russian enterprises characteristic with a complex multi-level management structure.

The company organizational structure involves the enterprise division into separate divisions and services (responsibility centers), in order to distribute between them the functions of solving the tasks set by the administration in the course of production activities to achieve final results.

As a rule, all industrial organizations in their organizational structure have a marketing department (sales department), which from the view point of identifying responsibility centers can be considered as a income center, and the retail outlet presence (retail store) or a trading company (wholesale trade) makes it possible to designate this object as a profit center. The investment center for today within the framework of industrial enterprises is rather difficult to allocate, since the control over the funds investment in structural subdivisions is carried out not by one but by several organization services (the planning and economic analysis service, the capital construction department, the accounting service).

In our opinion, such approach to the responsibility allocation centers makes it difficult to assess the labor use effectiveness, material and financial resources by individual structural units, which in turn makes it difficult to make effective management decisions in developing new products types or developing new markets.

It is important to note that the management accounting introduction for responsibility centers in an enterprise can sometimes cause serious difficulties due to various reasons. The main ones are the following:

1. the complexity of the responsibility centers organization;

2. the lack of a local computer network, a unified document management system, a clear organizational and functional structure;

3. the significant complexity selection of information focused on the strategic goals implementation and the enterprise objectives, etc.

From the above, we can conclude that the responsibility center concept within the management accounting system framework is an accounting system that provides reflection, accumulation and provision information analysis about costs and final results, allows to evaluate and monitor the structural units and specific managers performance.

Thus, the management accounting organization on responsibility centers for the economic entity activities is the most important mechanism for effective and timely monitoring and management, allowing to provide accounting and information focusing on processes and technologies that promote development and increase their efficiency, ensure high quality and innovativeness that meet the requirements of consumers and necessary to strengthen competitive advantage. The management accounting introduction can ensure the information flows interconnection in the implementing management objectives process. The lack of an effective mechanism for recording information and its processing technology leads to the formation of a weakly operating and poorly performing management system in agricultural organizations.

Each individual responsibility center is the part of the enterprise management system and has an input and output. Entry: raw materials, materials, semi-finished products, different hour types of labor and different service types. The each responsibility center activities 
can be assessed in terms of effectiveness. Although the resources used for production, in most cases, have a natural-material form, for management control purposes they must be presented in monetary terms in order to combine physically dissimilar resources elements. The monetary resources dimension used in the responsibility center is their value. 16 If the responsibility center output is sold to external customers, accounting measures it in the form of income. If goods or services are sent to other responsibility centers of the same organization, then they can be measured, either in monetary form or in nonmonetary form.

\section{Conclusion}

Thus, the enterprise management through responsibility centers is a tool for those who wants to manage and influence the business operatively. It also can have a systematic understanding of the directions and enterprise development rates; to understand, the reasons of making achieved result possible; to know which part of the company blunts the movement; to identify the most effective company divisions, by acting on which you can achieve maximum effect and high-quality new results

\section{References}

1. M.A. Vakhrushin, Management accounting: A textbook for universities, 2,12 (2002)

2. V.B. Ivashkevich, Management accounting: Textbook for universities, 56 (2003)

3. G.I. Konovalova, Cost management problems in an industrial enterprise, Management in Russia and abroad, 1, 97-99 (2018)

4. S. Kuznetsova, V. Markova, SWOT-analysis: the practice of application, Problems of the theory and practice of management, 5, 86-91 (2018)

5. T.A. Lunina, Problems of cost management associated with product quality, Economic Analysis: Theory and Practice, 14, 5257 (2015)

6. V.F. Nesvetaylov, Strategic management accounting at energy enterprises, diss. . doc., 435 (2012)

7. N. Plaskova, Strategically analysis and its role in substantiating the development strategy of the organization, Problems of theory and management practice, 1, 86-97 (2018)

8. M. Romanova, Controlling as a means of strategic 'enterprise management, Problems of the theory and practice of management, 4, 80-85 (2017)

9. S.A. Samusenko, New Trends in Accounting by Responsibility Centers, Economic Analysis: Theory and Practice, 15 (2016)

10. Yu.I. Sigidov, A.A. Adamenko, M.S. Rytyantsev, A systematic approach to the classification of cost accounting methods, Management Accounting, 2, 27-34 (2015)

11. A.A. Troitsky, Energy and the Economy of Russia: Past, Present and Future, Energy, 9-10, 2-12 (2003)

12. O.A. Fil, Managerial and strategic cost accounting of enterprises of the energy complex, diss. cand., 200 (2011)
13. N. Khakhonov, Principles of organization of management accounting of cash flows by responsibility centers, Modern high technology, 5356 (2006)

14. Ch.T. Horngren, J. Foster, Accounting: management aspect, Finance and Statistics, 146 (1995)

15. M. Fritz, M. Koch, Potentials for prosperity without growth: Ecological sustainability, social inclusion and the quality of life in 38 countries, Ecological Economics, 108, 191-199 (2014) 